\title{
Induction of defense mechanisms involved in disease resistance of onion blight disease caused by Botrytis allii
}

\author{
Mohamed M A Hussein ${ }^{1}$, Kamal A M Abo-Elyousr ${ }^{1 *}$ (D), Mohamed A H Hassan ${ }^{1}$, Mohamed Hashem², \\ Elhagag Ahmed Hassan ${ }^{3}$ and Saad A M Alamri
}

\begin{abstract}
Botrytis umbel blight caused by Botrytis allii is a major disease that attacks onion crop. In vitro, Trichoderma viride, Penicillium chrysogenum, and Saccharomyces cerevisiae and extract of bitter apple fruits (Citrullus colocynthis) showed antagonistic effect and inhibited the mycelial growth of B. allii. Gas chromatography-mass spectrometry (GC-MS) analysis of bitter apple fruits showed the existence of 37 compounds and their derivatives. Among them, 10 compounds constituted $58.66 \%$ of the total analyses. Greenhouse experiment approved that the extract of bitter apple fruits was the most effective in reducing disease incidence and severity, followed by $P$. chrysogenum, when they were applied 2 days pre-inoculation with the pathogen. All treatments significantly increased the total phenolic contents than the untreated control, but the highest increase was obtained when S. cerevisiae and $P$. chrysogenum were applied. A positive correlation was found between the activity of bioagents and improvement of peroxidase and phenylalanine ammonia-lyase enzymes in onion plants to resist infection with the pathogen. $P$. chrysogenum caused the highest increase in polyphenoloxidase activity in infected onion plants, while S. cerevisiae showed the lowest level of this enzyme. The study approved that application of the bioagents not only protected the onions against Botrytis disease but also enhanced the content of antioxidant compounds in onions. This encourages the application of such preparations to manage the production of onion crop, especially in the organic farming that bans the application of any chemicals.
\end{abstract}

Keywords: Antioxidant enzymes, Bioagents, Bitter apple fruits, Botrytis allii, Onion

\section{Background}

Onion, Allium cepa $L$., is one of the most important vegetable crops worldwide. Because of its high content of nutrients and flavors, it comprises a significant additive to the human diet (Arshad et al. 2017). A positive relationship between onion intake and low risk for the common disease of human was shown (Eltaweel 2013). Onion plants are rich in a wide variety of secondary metabolites and phytochemicals including the organosulfur compounds such as cepaenes and thiosulfinates (Lee and Mitchell 2011) and flavonoids such as quercetin and kaempferol (Dorant et al. 1994).

\footnotetext{
* Correspondence: kaaboelyousr@agr.au.edu.eg

${ }^{1}$ Plant Pathology Department, Faculty of Agriculture, Assiut University, Assiut 71526, Egypt

Full list of author information is available at the end of the article
}

There are different species of Botrytis related to onions in storage, but the rot encouraged by $B$. allii causes the greatest commercial loss. The umbel blight disease caused by $B$. allii was estimated as a subversive disease affecting the yield of onion seeds (Hussein et al. 2014). It is important to avoid the application of the chemical pesticides in the control of plant diseases, and the organic production of the crops should be encouraged. Biological control is an alternative method to the fungicides that achieved remarkable success in the control of plant disease (Reddy et al. 2014). Biological control strategies include the application of beneficial microbes, their metabolic derivatives, plant extracts, essential oils, or any organic-based material to suppress the disease and its causal pathogens (Thakur 2017).

Recently, the induction of plant resistance by the application of many microorganisms or organic materials 
has emerged as a new strategy in the management of plant diseases (Rais et al. 2017). Plants are a storehouse of natural compounds that subscribe in suppressing phytopathogens (Sales et al. 2016) of which plants supply a worthy source of active natural chemicals such as flavonoids, alkaloids, cucurbitacin, terpenoids, and glycosides (Koul and Walia 2009). Many reports showed that in addition to their suppression of plant pathogens, some natural plant products increased oxidative enzymes in plants that can play an important role in the resistance (Senthilraja et al. 2013; Raj et al. 2016). The antioxidant enzymes peroxidase (PO), phenylalanine ammonia-lyase (PAL), and polyphenoloxidase (PPO) were mentioned as elicitors of the systemic resistance (ISR) in the plants that have a correlation with disease control (Yasmin et al. 2016). These enzymes are involved in the production of phenolic compounds that support the cell barriers against pathogens' attack (Nascimento et al. 2016). Meanwhile, generation of ROS (reactive oxygen species) during oxidative burst may directly be involved in pathogen recognition, then pathogen killing, and systemic resistance signaling (Shoaib et al. 2018).

We assume that the application of biocontrol agents (microorganisms and natural products) to increase phenol and antioxidant contents that consequently increases the resistance of onion against the pathogens is a twofold strategy, which makes the onion self-suppressive to the pathogens, and to increase its nutritional and medical values.

Therefore, this work was planned to study the effectiveness of bioagents against onion blight disease via increasing the content of antioxidants and resistance-inducers such as total phenol contents and enzymatic changes.

\section{Materials and methods Onion plant}

Onion seeds (cv. Giza 6) were germinated under greenhouse conditions at $20 \pm 2{ }^{\circ} \mathrm{C}$ during the day and $18 \pm 2^{\circ}$ $\mathrm{C}$ during the night. After 4 weeks, the seedlings were transplanted into $30-\mathrm{cm}$-diameter plastic pots containing sandy loam soil.

\section{Isolations of the causal pathogens}

Onion leaves, showing Botrytis onion umbel blight "BOUB" disease symptoms, were collected from different localities of onion seed production in Assiut governorate, Egypt. Isolation was carried out from the diseased leaves as described by Abdel-Hafez et al. (2015). Leaves were cut into small pieces, thoroughly washed with tap water, and sterilized for $2 \mathrm{~min}$ in $2 \%$ sodium hypochlorite solution. Then, the pieces were rinsed several times in sterilized distilled water, dried with sterilized filter papers, plated onto Potato Dextrose Agar (PDA) medium, and incubated at $27{ }^{\circ} \mathrm{C}$. The antibiotic procaine penicillin was added to the medium after autoclaving (60 units/ $\mathrm{ml})$. After 4-5 days of incubation, the developing fungi were purified by a single spore technique on the same medium. The pure cultures of the isolated fungi were kept in a refrigerator at $4{ }^{\circ} \mathrm{C}$ for further use. They were identified according to their cultural and microscopical characteristics (Ellis 1971; Domsch et al. 1980).

\section{Preparation of the pathogen inoculum}

The inoculum of $B$. allii, isolated from diseased onion, was prepared from stock cultures on PDA stored at $4^{\circ}$ C. It was inoculated onto PDA in a 9-cm-diameter Petri dish and incubated at $25 \pm 1{ }^{\circ} \mathrm{C}$ for 15 days under a 12 -h photoperiod using the near-ultraviolet light. Ten milliliters of sterile distilled water was added to each plate, and the colonies were scraped with a sterile needle. The obtained conidial suspension was diluted to $5 \times 10^{4}$ $\mathrm{CFU} / \mathrm{ml}$ and sprayed onto leaves and seedstalks of onion plants (110-day-old), using an atomizer at the rate of $10 \mathrm{ml} /$ plant.

\section{Isolation and selection of antagonistic microorganisms}

The antagonistic microorganisms were isolated from the phyllosphere and the rhizosphere of healthy onions using a standard dilution plate (Ishaq and Khan 2011). Identification of the obtained microorganisms was carried out using the identification manuals based on the macro- and microscopical characteristics (Rifai 1969; Ainsworth 1971; Ellis 1971; Pitt 1979).

These microorganisms were tested for their antagonistic capabilities in vitro against $B$. allii by using the dual culture method (Hazarika and Das 1998) on PDA. The Petri dishes were incubated at $25 \pm 1{ }^{\circ} \mathrm{C}$ till the control plates were completely covered with $B$. allii (7 days). The reduction percentage in the linear growth of the pathogen was calculated, using the following formula: $R$ $=(C-T / C) \times 100$, where $R$ is the percentage of growth reduction, $C$ is the diameter of the fungal growth in the control, and $T$ is the diameter of the fungal growth in the treatment (Bouziane et al. 2011).

\section{Plant extracts}

Fresh healthy bitter apple fruits, Citrullus colocynthis; basil, Ocimum basilicum, leaves; and mustard, Sinapis arvensis, were washed thoroughly in cold running tap water, then with sterilized water, and air-dried for 20 days and separately micronized with a hammer mill into a fine powder. Two hundred grams of each powder of material was added to $300 \mathrm{ml}$ distilled water in the ratio of 2:3 $(\mathrm{w} / \mathrm{v})$ and were shaken for $24 \mathrm{~h}$ at $200 \mathrm{rpm}$. The pulverized mass of plant leaves was squeezed through a double-layered muslin cloth and then centrifuged at $5000 \mathrm{rpm}$ for $20 \mathrm{~min}$ at $4{ }^{\circ} \mathrm{C}$. The supernatant was sterilized by passing it through a bacterial 
filter $0.20 \mu \mathrm{m}$ (Seitz). The plant extract was collected in sterilized brown bottles and kept in a refrigerator at $4{ }^{\circ} \mathrm{C}$ until used as standard plant extract solution (100\%) (Abo-Elyousr and Asran 2009). The antagonistic effect of plant extracts was evaluated in vitro by mixing $20 \mathrm{ml}$ PDA medium with each concentration of the plant extracts $(1$, 5 , and $10 \%)$. The dishes were inoculated aseptically with an 8-mm-diameter agar disc of 7-day-old culture of B. allii. PDA medium without the plant extract served as control. Five replicates were used for each treatment (Singh and Tripathi 1999). Dishes were incubated at $25{ }^{\circ} \mathrm{C}$ for 7 days. Reduction percentage in the linear growth of the pathogen was determined as mentioned before (Bouziane et al. 2011). Fungicide "Ridomil Gold MZ" at concentration $0.2 \%$ was used as a positive control in the case of bioagents.

The chemical components of bitter apple dried fruits were analyzed by GC-MS (gas chromatography-mass spectrometry) at the Analytical Chemistry Unit, Assiut University, Egypt. Identification of the chemical constituents was made, using Hewlett Packard HB 7890A gas-liquid chromatography (GLC) coupled with 5975B series mass spectrometer (Mass). Identification of the individual components was performed by comparison of mass spectra with the profiles from the Wiley GC-Mass 275 libraries.

\section{Efficiency of the bioagents in control onion blight disease in vivo}

The experiments were carried out in pots under the greenhouse conditions. Pots (30 $\mathrm{cm}$ in diameter) were sterilized by immersing in $5 \%$ formalin solution. The inoculum of $B$. allii was prepared as mentioned before. It was used at the concentration of $5 \times 10^{4} \mathrm{CFU} / \mathrm{ml}$ to inoculate the 120-day-old onion plants, using a hand atomizer (10 ml/plant). Trichoderma viride, Penicillium chrysogenum, and Saccharomyces cerevisiae were chosen as the best ones in each genus, based on the in vitro results. Bioagents were applied 2 days after inoculation with the pathogen by spraying $10 \mathrm{ml}$ of each preparation (Hussein et al. 2007) supplemented with 1\% Arabic gum as a sticker (Ziedan 1998). The supernatant of bitter apple fruits (C. colocynthis) was taken as a standard solution (100\%) as described previously. Further, the extract was diluted at $5 \%$ concentration. Ten milliliters of $5 \%$ bitter apple extract was sprayed on onion plants, 2 days after pathogen inoculation, as bioagent. The fungicide "Ridomil Gold MZ" was used as a positive control in case of fungi and plant extract.

\section{Analysis}

\section{Weight of onion seeds}

The seeds were harvested by cutting off the umbels, then dried in sunlight for 5 days, and threshed manually using shaken sieves. After cleaning of threshed seeds, the seeds were dried and kept in paper bags then stored properly at room temperature to be weighted. Umbels were selected randomly from each plot, and data were recorded on individual umbel seeds; thousand seed weight (TSW) in grams was evaluated.

\section{Biochemical changes in onion plants}

Samples of healthy and infected plants were taken at different intervals after treatments $(2,4,6$, and 8 days) and were analyzed for their phenolic contents and enzymatic activity.

\section{Total phenol contents}

Seed heads (umbels) and plant leaf samples were immersed in liquid $\mathrm{N}_{2}$, homogenized in $80 \%$ methanol (1-g plant material in $10 \mathrm{ml}$ methanol), and stored in deep freeze at $-20{ }^{\circ} \mathrm{C}$. The homogenates were centrifuged at $10,000 \mathrm{rpm}$ for $15 \mathrm{~min}$ at $4{ }^{\circ} \mathrm{C}$, the pellet was discarded after addition of ascorbic acid $(0.1 \mathrm{~g}$ for $5 \mathrm{ml}$ methanol), and the homogenates were evaporated in a rotary evaporator at $65{ }^{\circ} \mathrm{C}$ and repeated three times for $5 \mathrm{~min}$. The residues were dissolved in $5 \mathrm{ml} \mathrm{80 \%} \mathrm{metha-}$ nol. Three replicates were used for each treatment (Hoevermann et al. 1973). Total phenolic content of the samples was estimated, using Folin-Ciocalteau reagent. Folin-Ciocalteau reagent was diluted ten times using deionized water. The diluted reagent $(0.75 \mathrm{ml})$ was mixed with $0.1 \mathrm{ml}$ sample and held at room temperature for $5 \mathrm{~min} .0 .75 \mathrm{ml}$ of $2 \%$ sodium carbonate solution was added. After a 15-min incubation at room temperature, the absorbance of the solution was determined at OD $750 \mathrm{~nm}$ by $2 \mathrm{D}$ spectrophotometer. Blank samples were made by replacing Arnow's reagent (10 g sodium nitrite and $10 \mathrm{~g}$ sodium molybdate made up to $100 \mathrm{ml}$ with distilled water) with distilled water in the reaction mixture. The standard curve was made by using catechol (1-10 mg). The unit of TPC assay was expressed by milligram catechin equivalent/gram dry weight (Velioglu et al. 1998; Sun et al. 2007).

\section{Enzymatic activity \\ Peroxidase activity $(\mathrm{PO})$}

Peroxidase activity (PO) in onion plant leaves was performed, $1 \mathrm{~g}$ fresh weight leaves of onion plants homogenizing with $10 \mathrm{ml} 0.1 \mathrm{M} \mathrm{Na-acetate}$ buffer $\mathrm{pH}$ 5.2. The mixture was centrifuged for $30 \mathrm{~min}$ $10,000 \mathrm{rpm}$ at $4{ }^{\circ} \mathrm{C}$; the supernatants were collected for measuring the enzyme activity. Peroxidase activity was determined spectrophotometrically, using guaiacol as a common substrate for peroxidase. The homogenate of $0.2 \mathrm{ml}$ was incubated with $0.1 \mathrm{ml}$ of $0.1 \mathrm{M} \mathrm{Na}$-acetate-buffer (pH 5.2), $0.2 \mathrm{ml} \mathrm{1 \%}$ guaiacol, and $0.2 \mathrm{ml} \mathrm{1 \%} \mathrm{H}_{2} \mathrm{O}_{2}$ at $25{ }^{\circ} \mathrm{C}$ for $5 \mathrm{~min}$ and measured at $436 \mathrm{~nm}$ (Chance and Maehly 1955). Na-acetate buffer was used as a 
blank. Enzyme activity was calculated from the change in absorbance and was expressed as peroxidase activity $=\mathrm{OD}_{436} \mathrm{~nm} / \mathrm{mg}$ protein.

\section{Polyphenoloxidase activity (PPO)}

Homogenate onion fresh leaves solution $(0.5 \mathrm{ml})$, as mentioned in peroxidase activity, was incubated with $2 \mathrm{ml} 50 \mathrm{mM}$ Sorensen (phosphate buffer) and $0.5 \mathrm{ml}$ substrate brenzcatechol (Sigma Aldrich) at $37{ }^{\circ} \mathrm{C}$ for $2 \mathrm{~h}$ and measured at OD $410 \mathrm{~nm}$ (Batra and Kuhn 1975).

\section{Phenylalanine ammonia-lyase (PAL)}

Homogenate onion fresh leaves solution $(0.5 \mathrm{ml})$ was incubated by $2 \mathrm{ml}$ of $50 \mathrm{mM}$ Na-borate buffer/ $\mathrm{HCl}$ $(\mathrm{pH} 8.8)(25 \mathrm{ml} \mathrm{NaOH}$ of $1.0 \mathrm{~N}), 3.09 \mathrm{~g} \mathrm{H}_{3} \mathrm{BO}_{3}$, and $349 \mu \mathrm{l}$ mercaptoethanol, dissolved in $1000 \mathrm{ml}$ distilled water, and then, the $\mathrm{pH}$ was adjusted to 8.8 with $1 \mathrm{ml}$ of $60 \mathrm{mM}$ phenylalanine, in $50 \mathrm{mM}$ Na-borate-buffer at $37{ }^{\circ} \mathrm{C}$ for $2 \mathrm{~h}$. PAL activity was determined spectrophotometrically, using spectrophotometer UniCam-UV, calculated at $\mathrm{OD} 290 \mathrm{~nm}$. Cinnamic acid $(0-5.0 \mathrm{mg})$ was used as a standard. Activity was determined as the rate of conversion of L-phenylalanine to trans-cinnamic acid at OD $290 \mathrm{~nm}$ (Lisker et al. 1983).

\section{Statistical analysis}

All greenhouse experiments were arranged in a completely randomized split-plot design, with three replicates of 12 plants for each treatment, and repeated twice. Each sample of the extract was measured twice in each replicate, and at least three replications were performed per analysis. The significance of differences between mean values was determined. Analysis of variance (ANOVA) was carried out, and the significance of differences among the treatments was determined according to least significant difference (LSD) $P=0.05$ (Gomez and Gomez 1984).

\section{Results and discussion}

Isolation and identification of the microorganisms

Based on the cultural and microscopical characteristics, the causal pathogen was identified as Botrytis allii. Using the identification manuals, the antagonistic microorganisms were identified as Acremonium strictum, Gliocladium roseum, Penicillium chrysogenum, P. purpurogenum, Saccharomyces cerevisiae, Trichoderma harzianum, $T$. hamatum, T. longirum, T. viride, T. koningii, and $T$. pseudokoningii.

\section{Antagonistic effects of the bioagents in vitro}

All tested bioagents were able to inhibit the mycelial growth of B. allii, but with different capabilities (Table 1). The highest percentage of inhibition was achieved by $T$. viride isolate 1 (86\%), T. harzianum isolate 1 (85\%), $T$.
Table 1 Inhibitory effect of the tested bioagents and plant extracts against Botrytis allii in vitro

\begin{tabular}{|c|c|}
\hline Isolates & Mycelial growth inhibition (\%) \\
\hline Trichoderma harzianum isolate 1 & $85^{\mathrm{bc}}$ \\
\hline T. harzianum isolate 2 & $80^{d}$ \\
\hline T. harzianum isolate 3 & $60^{h}$ \\
\hline T. harzianum isolate 4 & $56^{i}$ \\
\hline T. harzianum isolate 5 & $55^{i}$ \\
\hline Trichoderma hamatum isolate 1 & $64^{9}$ \\
\hline T. hamatum isolate 2 & $68^{f}$ \\
\hline T. hamatum isolate 3 & $60^{h}$ \\
\hline Trichoderma longirum isolate 1 & $34^{\circ}$ \\
\hline T. longirum isolate 2 & $34^{\circ}$ \\
\hline Trichoderma viride isolate 1 & $86^{\mathrm{b}}$ \\
\hline T. viride isolate 2 & $84^{c}$ \\
\hline Trichoderma koningii isolate 1 & $56^{i}$ \\
\hline T. koningii isolate 2 & $60^{h}$ \\
\hline Trichoderma pseudokoningii & $34^{\circ}$ \\
\hline Acremonium strictum & $55^{i}$ \\
\hline Gliocladium roseum & $52^{j}$ \\
\hline Saccharomyces cerevisiae isolate 1 & $55^{i}$ \\
\hline S. cerevisiae isolate 2 & $45^{1}$ \\
\hline S. cerevisiae isolate 3 & $50^{k}$ \\
\hline Penicillium chrysogenum isolate 1 & $74^{\mathrm{e}}$ \\
\hline P. chrysogenum isolate 2 & $43^{m}$ \\
\hline Penicillium oxalicum isolate 1 & $68^{f}$ \\
\hline Penicillium oxalicum isolate 2 & $40^{n}$ \\
\hline Penicillium purpurogenum & $55^{i}$ \\
\hline Ridomil Gold MZ & $100^{\mathrm{a}}$ \\
\hline
\end{tabular}

Values in the column followed by different letters indicate significant differences among treatments according to LSD at 0.05

viride isolate $2(84 \%)$, and $P$. chrysogenum (74\%). However, $T$. pseudokoningii and $T$. longirum recorded the lowest inhibition percentage of mycelial growth, being $34 \%$. The other tested microorganisms showed a relatively low inhibitory effect on the growth of the fungal pathogen.

Results in Table 2 indicate that all tested plant extracts were able to inhibit the mycelial growth of the causal pathogen, but their toxicity was varied. The highest inhibition of $B$. allii (70\%) was caused by C. colocynthis extract at the concentration of $10 \%$; however, the extract of $S$. arvensis and $O$. basilicum showed the low percentages of inhibition even at high concentrations. Based on the in vitro results, the highest one isolate in each fungal species, T. viride isolate $1, P$. chrysogenum, and $S$. cerevisiae isolate 2 , and the extract of $C$. colocynthis (10\%) were selected to conduct the subsequent in vivo experiments. 
Table 2 Effect of some plant extracts on the growth of Botrytis allii, the causal of Botrytis onion umbel blight (BOUB) diseases, in vitro

\begin{tabular}{lll}
\hline Plant extract & Concentration (\%) & Mycelial growth inhibition (\%) \\
\hline C. colocynthis & 1 & $30^{\mathrm{d}}$ \\
& 5 & $47^{\mathrm{c}}$ \\
& 10 & $70^{\mathrm{b}}$ \\
S. arvensis & 1 & $20^{\mathrm{ef}}$ \\
& 5 & $20^{\mathrm{ef}}$ \\
& 10 & $22^{\mathrm{ef}}$ \\
O. basilicum & 1 & $24^{\mathrm{de}}$ \\
& 5 & $24^{\mathrm{de}}$ \\
& 10 & $24^{\mathrm{de}}$ \\
Ridomil Gold MZ & 0.2 & $100^{\mathrm{a}}$ \\
\hline
\end{tabular}

Values in the column followed by different letters indicate significant differences among treatments according to LSD at 0.05

Using fungicides is still the effective method in the control of plant diseases; however, their extensive applications had a negative impact such as an appearance of new fungicide-resistant pathogenic strains, contamination of the environment, and modification of the equilibrium of the beneficial microorganisms (Abdel-Rahim and Abo-Elyousr 2018). Recently, many studies have been carried out, using different applications that rely on the biological basis to control the plant diseases (Abdel-Hafez et al. 2015; Abo-Elyousr et al. 2010). The current results showed that the use of different bioagents including fungal species, yeast species, and aqueous extract of bitter apple was able to inhibit the mycelial growth of $B$. allii-the causal pathogen of Botrytis umbel blight disease. These results were supported by other findings that approved the efficiency of many bioagents in biocontrol of plant diseases (Wang et al. 2010; Soria et al. 2012; Abo-Elyousr et al. 2014). Trichoderma spp. as classical microorganisms were used in many cases and had been paid attention by the scientists and users. The mechanisms by which these fungi could suppress their target pathogens include competition for space and nutrients, mycoparasitism, and induction of plant resistance against the pathogens (Zimand et al. 1996; Elad and Kapat 1999).

\section{Chemical analysis of the aqueous extract of bitter apple}

Data of GC-MS of the aqueous extract of C. colocynthis resulted in the identification of 37 compounds and their derivatives. Among them, 10 compounds constituted $58.66 \%$ of the total analyses that were considered the main constituents (Table 3). The most intensive components were 9,12-octadecadienoic acid, 1,2-benzenedicarboxylic acid, 4,5,6,7-tetrachloro-3ethoxy-1H-isoindole, and gamma-tocopherol, followed by palmitic acid beta-monoglyceride, squalene, 3-(2-
Table 3 Chemical compounds having the total percentage of GC-MS chemical analysis of the aqueous extract of Citrullus colocynthis

\begin{tabular}{lll}
\hline Compound name & RT (min) & Mol. weight \\
\hline 9,12-Octadecadienoic acid & 19.134 & 280.24 \\
1,2-Benzenedicarboxylic acid & 25.892 & 390.277 \\
4,5,6,7-Tetrachloro-3-ethoxy-1H-isoindole, & 45.870 & 296.928 \\
Gamma-tocopherol & 39.605 & 416.365 \\
Palmitic acid, beta-monoglyceride & 25.497 & 330.277 \\
Squalene & 33.176 & 410.391 \\
3-(2-Methylphenoxy) pyridazine & 38.750 & 186.079 \\
Hexadecanoic acid & 9.876 & 328.28 \\
Oxalic acid & 36.021 & 398.227 \\
Octadecanoic acid & 31.005 & 358.308 \\
\hline
\end{tabular}

methylphenoxy) pyridazine, and oxalic acid. The other 27 compounds were detected in low or very low concentrations, and they were omitted from Table 3.

Lattanzio et al. (1996) mentioned that dimethoxybenzoic acid and many of its derivative compounds can play a role against post-harvest disease in strawberry caused by Botrytis cinerea. Avis (2007) reported that fatty acids in the form of phospholipids are important components of the lipid bilayer of the cell membrane of all cells. The cell membrane has an essential general role of maintaining cell order and integrity, and a number of disease control mechanisms involve the compounds that directly affect by partitioning into the membrane and inducing disorders or indirectly affect by inhibiting fatty acid biosynthetic pathways that target the phospholipids of the cell membrane. Recent research has also shown that 2-hexadecynoic acid, a 2-alkynoic fatty acid, had antibacterial activity against Mycobacterium tuberculosis and that linoleic acid (18:2), a polyunsaturated fatty acid, has antifungal activity against several plant pathogenic fungi (Liu et al. 2008).

The imidazole is one of the derivatives that exist in $C$. colocynthis aqueous extract and has biological effects. One hundred nanomolars of imidazole is about five times less potent than clotrimazole $(18 \mathrm{nM})$, miconazole $(28 \mathrm{nM})$, and tioconazole $(20 \mathrm{nM})$ on the inhibition of Cytochrome P450 3A4 (CYP3A4) in vitro (Ballard and Lodola 1988). The dimeric carbazole was found to be the most potent compound against the Gram-negative bacteria (Escherichia coli and Proteus vulgaris) and fungi Aspergillus niger and Candida albicans (Rahman and Gray 2005).

Effect of the bioagents on disease development under greenhouse conditions (in vivo)

Application of fungicide (Ridomil Gold MZ) on onion plants caused the highest reduction of disease severity 
by $98.0 \%$ (Table 4). Application of C. colocynthis extract, 2 days before infection with the pathogen, was involved in the highest reduction in the disease severity by $72.2 \%$, followed by $P$. chrysogenum (56\%). On the other hand, the highest reduction in disease severity was achieved in the case of $P$. chrysogenum and $T$. viride, when they were applied 2 days after infection as 65 and 63.9\%, respectively, while the lowest inhibitory effect was attributed to S. cerevisiae, being $36.1 \%$.

Seed weight was influenced by using the different bioagents and showed significant variations (Fig. 1). Among the treatments applied before infection, the highest weight of 1000 seeds $(2.88 \mathrm{~g})$ was obtained in the case of $P$. chrysogenum, followed by the extract of $C$. colocynthis, while the lowest weight $(1.8 \mathrm{~g})$ was obtained in the case of $T$. viride. Application of bioagents after infection recorded the highest TSW (4.08 g) as a result of using $C$. colocynthis extract, followed by $P$. chrysogenum $(2.64 \mathrm{~g})$. The TSW was significantly the lowest $(1.89 \mathrm{~g})$ due to $T$. viride treatment.

Treatments of onion cultivars with S. cerevisiae showed a moderate reduction in the disease severity. This result is in agreement with those obtained by Filonow et al. (1996). Application of bitter apple, C. colocynthis, and P. chrysogenum attained the highest reduction in disease severity. The results match with other findings obtained by Nagaraja et al. (2008) and Abdel-Monaim et al. (2011). The mode of action of plant extracts such as C. colocynthis, Sinapis arvensis, and Ocimum basilicum was not exactly understood, but some other plant extracts were studied and succeeded to control many plant diseases. In this respect, Fandohan et al. (2004) mentioned that seeds of the neem tree, Azadirachta indica, completely inhibited the growth of Fusarium verticillioides at a concentration higher than $2.7 \mu \mathrm{l} / \mathrm{ml}$.

The significant increase in seed weight of the treated plants is a good indicator of the efficiency of the treatment in the suppression of the diseases and production of healthy well-grown plants. Results showed a significant increase in the thousand seed weight in all treatments compared to the infected control. In another work, El-Aweel and Ghobashi (1999) mentioned that one of the reasons for increasing onion seed weight might be due to genetic or tolerance capability. Favorable environment conditions such as appropriate temperature could enhance the seed weight (Ud-Deen 2008).

\section{Effect of host-pathogen-bioagents interaction on the elucidation of resistance \\ Total phenol contents (TPC)}

All treatments increased TPC significantly than the untreated control ( $\mathrm{LSD}=1.5$ at $P \leq 0.05)$. S. cerevisiae was involved in the highest TPC, followed by $P$. chrysogenum and the extract of $C$. colocynthis. Two days after application, the treated plants showed significant differences in TPC among all treatments compared to the untreated plants (Fig. 2). After 8 days, all treatments increased TPC significantly compared to the infected control; however $P$. chrysogenum had the highest level. The results showed that application of $S$. cerevisiae, P. chrysogenum, and $C$. colocynthis increased significantly the total phenolic contents than the untreated plants, when the bioagents were applied after infection with the pathogen. After 8 days, all treatments caused significant increases in TPC compared to the infected control. Accumulation of phenolic compounds at the infection sites showed a correlation with the restriction of pathogen development, since such compounds are toxic substances to pathogens. Also, the resistance may be increased by change of $\mathrm{pH}$ of plant cell cytoplasm, due to the increase in phenolic acid content, resulting in inhibition of pathogen development (Khaledi et al. 2015). In addition, phenolic compounds may impede pathogen infection by increasing the mechanical strength of the host cell wall (Benhamou et al. 2000).

\section{Peroxidase activity (PO)}

Eight days post application, the treated plants by either bioagents showed a significant increment in peroxidase activity than any other times (Fig. 3). Application of $P$. chrysogenum and C. colocynthis exhibited higher enzyme

Table 4 Effect of different treatments with bioagents on disease severity (\%) of BOUB caused by Botrytis allii under greenhouse conditions

\begin{tabular}{|c|c|c|c|c|c|}
\hline \multirow[t]{2}{*}{ Treatments } & \multicolumn{2}{|c|}{ Treatments before infection } & \multicolumn{2}{|c|}{ Treatments after infection } & \multirow[b]{2}{*}{ Disease severity mean (\%) } \\
\hline & Disease severity (\%) & Disease reduction (\%) & Disease severity (\%) & Disease reduction (\%) & \\
\hline S. cerevisiae & $53.3^{\mathrm{b}}$ & 46.7 & $63.9^{\mathrm{b}}$ & 36.1 & 58.6 \\
\hline T. viride & $53.3^{\mathrm{b}}$ & 46.7 & $36.1^{d}$ & 63.9 & 44.7 \\
\hline P. chrysogenum & $44.0^{c}$ & 56.0 & $35.0^{\mathrm{d}}$ & 65.0 & 39.5 \\
\hline C. colocynthis & $27.8^{\mathrm{d}}$ & 72.2 & $43.3^{c}$ & 56.7 & 35.55 \\
\hline Ridomil Gold MZ & $2.00^{e}$ & 98.0 & $2.00^{\mathrm{e}}$ & 98.0 & 2.00 \\
\hline Infected control & $100^{\mathrm{a}}$ & 0.00 & $100^{\mathrm{a}}$ & 0.00 & 100 \\
\hline Healthy control & $0.00^{f}$ & 100 & 0.00 & 100 & 0.00 \\
\hline
\end{tabular}

Values in the columns followed by different letters indicate significant differences among treatments according to LSD at 0.05 


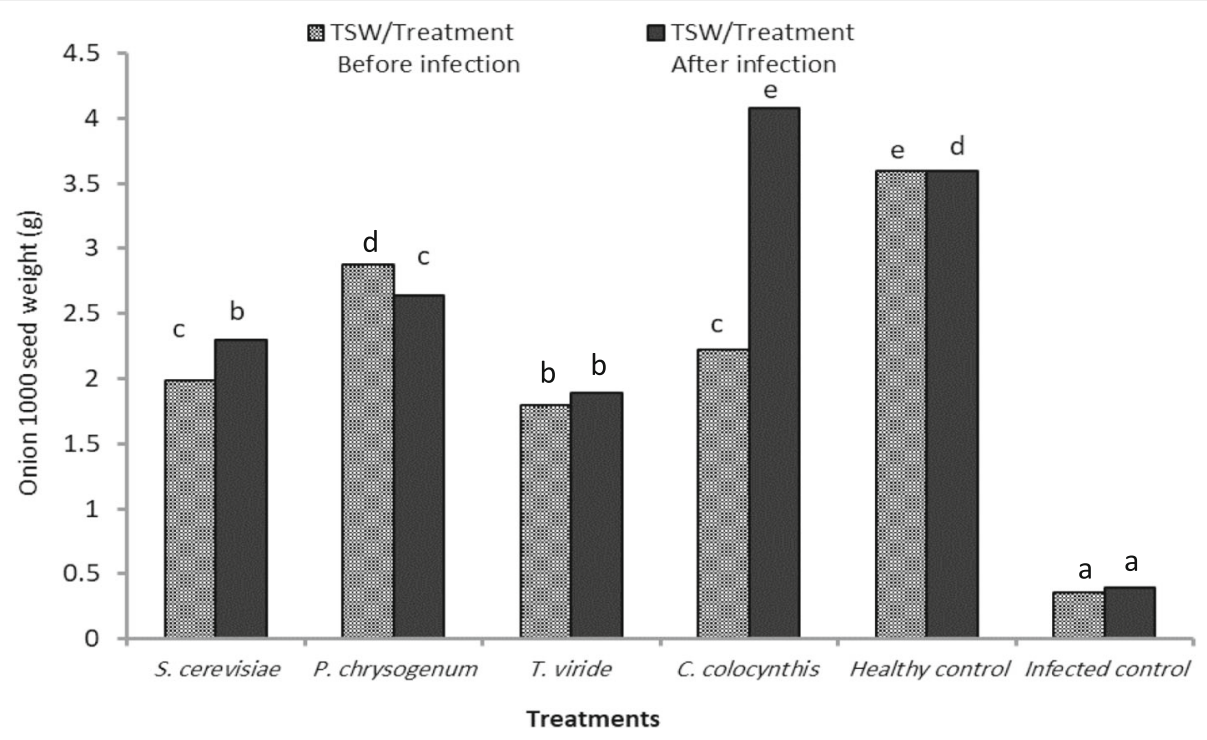

Fig. 1 Effect of treatments on weight of onion seeds. Columns in the same color having the same letter are not significantly different at $P \leq 0.05$

activity than the other treatments. The highest activity was achieved in the case of $P$. chrysogenum at the eighth and sixth days. The lowest activity of the enzyme was obtained when S. cerevisiae was applied; however, the increase was still significant compared with the infected control (LSD $=7.2$ at $P \leq 0.05)$.

Foliar treatment with the bioagents resulted in a significant increase in PO activity at all sampling times. The enhanced peroxidase activity was reported to be associated with the induced systemic resistance in plants against several pathogens (Baysal et al. 2005) and induced several plant defense mechanisms, such as lignin biosynthesis and oxidative cross-linking of plant cell walls, as well as the generation of oxygen species (Bestwick et al. 1998).
Peroxidase is involved in a broad range of physiological processes during the whole plant life cycle due to the catalytic, peroxidative, and hydroxylic cycles. Peroxidases can generate reactive oxygen species ( $\mathrm{ROS})(\mathrm{OH}, \mathrm{HOO})$, polymerize cell wall compounds, and regulate $\mathrm{H}_{2} \mathrm{O}_{2}$ levels (Seleim et al. 2014). These multifunctional enzymes can build a rigid wall or produce ROS to make it more flexible that can prevent biological attacks by raising physical barriers or by counterattacking with a large production of ROS.

\section{Polyphenoloxidase activity (PPO)}

Application of $P$. chrysogenum showed the highest increase in polyphenoloxidase activity in onion plants,

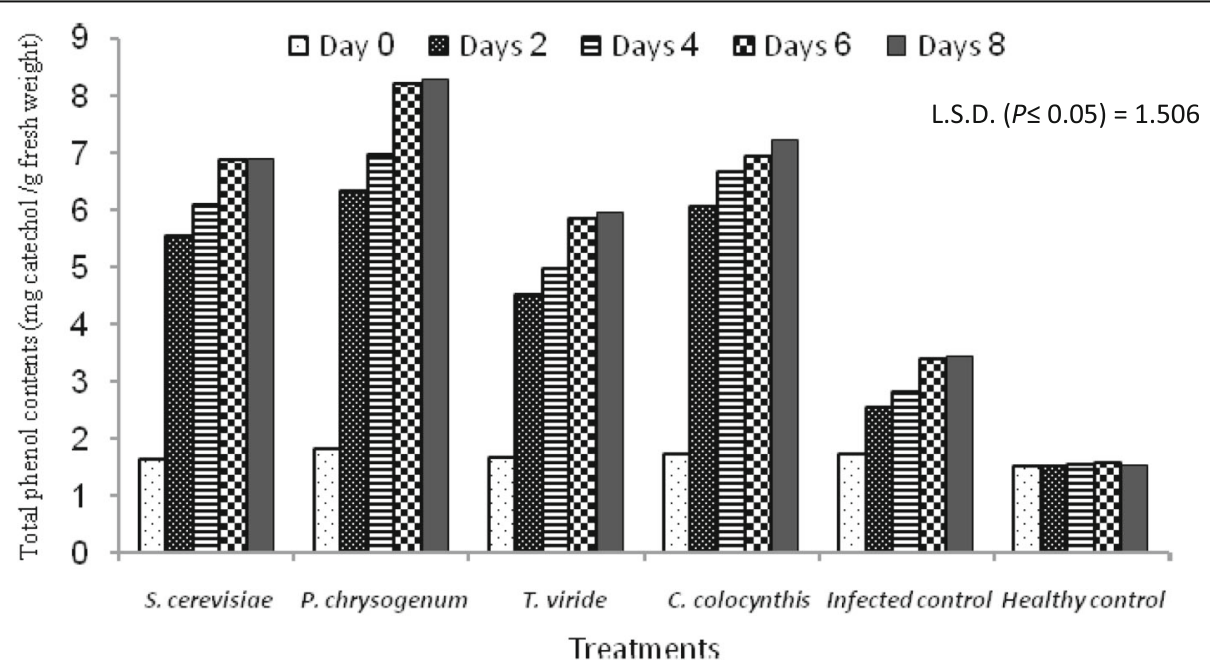

Fig. 2 Effect of application of bioagents and plant extract on total phenol contents (TPC) in onion plants 


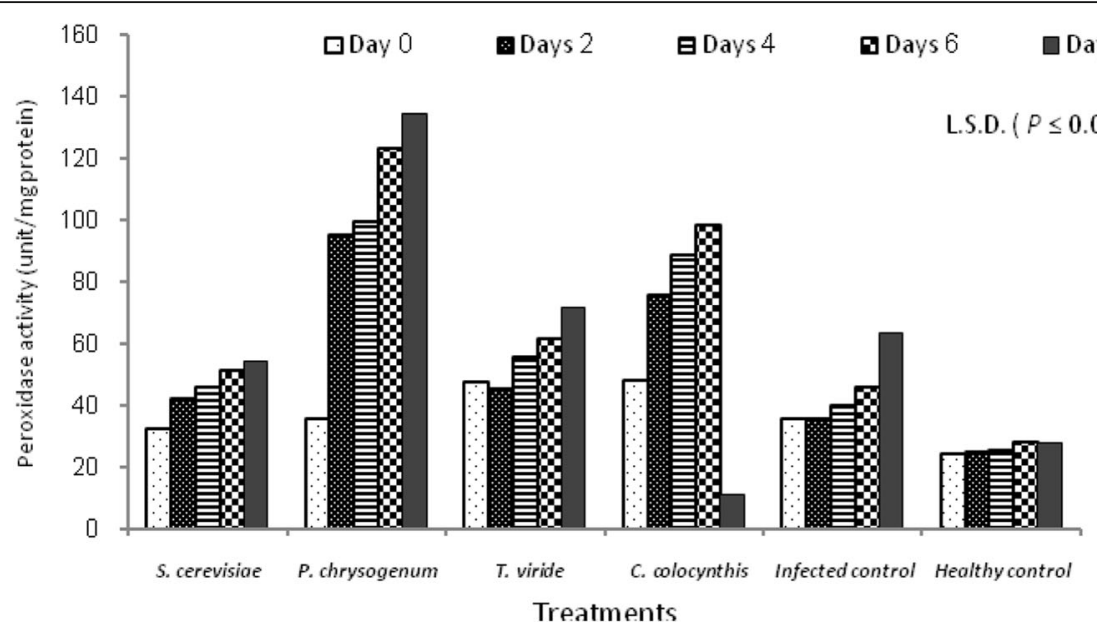

Fig. 3 Effect of application of bioagents and plant extract on peroxidase activity (PO) in onion plants

while S. cerevisiae showed the lowest activity of the enzyme (Fig. 4). After 8 days from application, the treated onion plants showed a significant variation in polyphenoloxidase activity among the treatments compared to the untreated plants $(\mathrm{LSD}=4.9$ at $P \leq 0.05)$. P. chrysogenum showed the highest activity of polyphenoloxidase at the eighth day than the other bioagents.

An increase in the activity of PPO was observed in onion plants treated with all bioagents; however, the highest PPO activities were achieved by $P$. chrysogenum. It was noticed that the level of PPO in the inoculated plants with the pathogen was relatively high compared to the healthy plants. PPO catalysis is the last step in the biosynthesis of lignin and other oxidative phenols. The mechanisms of PPO depend on two ways: firstly, by a direct action of PPO on the pathogen inhibition and suppression of its life cycle and secondly, induces mediated phenolic compounds which restrict the pathogen and enhance the biocontrol action (Mayer 2006; Seleim et al. 2014).

\section{Phenylalanine ammonia-lyase (PAL)}

Variance behavior was illustrated in Fig. 5, for PAL enzyme involved in the present investigation. Application of either bioagents increased the activity of phenylalanine ammonia-lyase compared to both infected or healthy controls. P. chrysogenum and C. colocynthis treatments enhanced the activity of PAL to the highest extent. $T$. viride also induced the enzyme's activity significantly compared to both infected and healthy controls, but lower than P. chrysogenum or C. colocynthis. Application

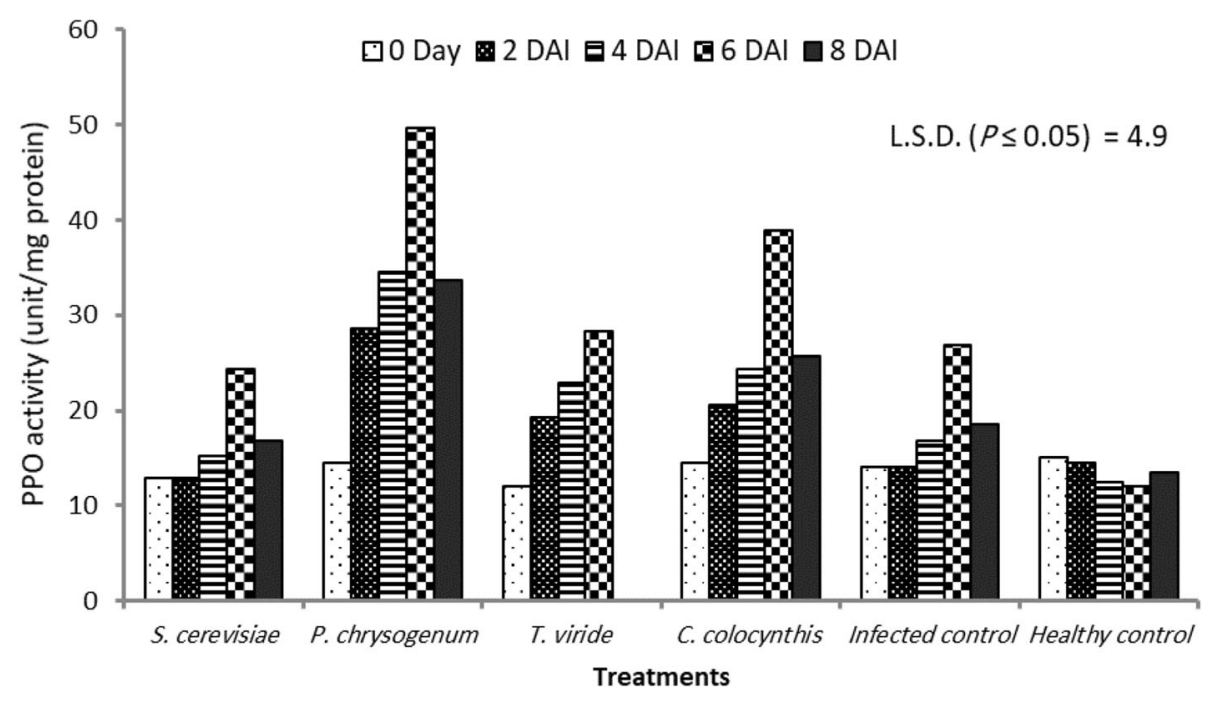

Fig. 4 Effect of application of bioagents and plant extract on polyphenoloxidase activity (PPO) in onion plants 


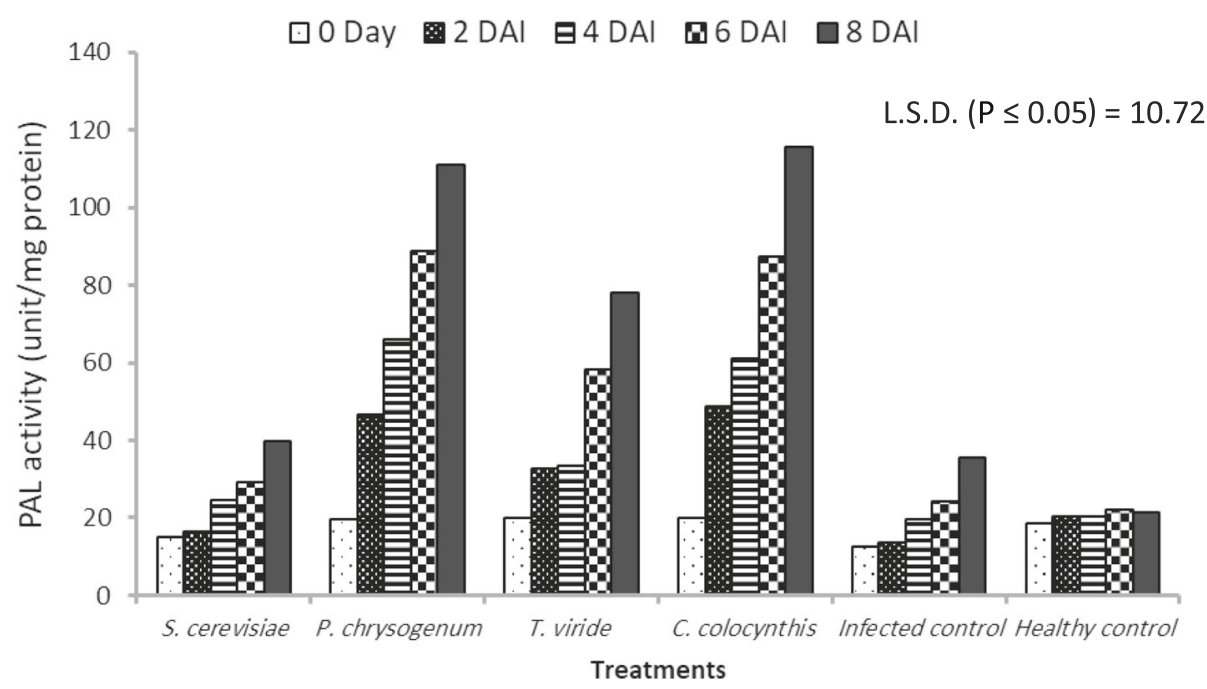

Fig. 5 Effect of application of bioagents and plant extract phenylalanine ammonia-lyase (PAL) activity in onion plants

of $S$. cervisiae attained the lowest activity of phenylalanine ammonia-lyase (LSD $=10.7$ at $P \leq 0.05)$.

The highest value in phenylalanine ammonia-lyase (PAL) activity was detected when C. colocynthis and $P$. chrysogenum were applied, followed by $T$. viride. The results are supported by those of $\mathrm{Yu}$ and $\mathrm{Du}$ (2018), who reported that in tobacco plants, a considerable increase in PAL activity was correlated to the formation of salicylic acid from cinnamic acid. Plants could be protected from the fungal infection by systemic induction of the encoding gene and pathogenesis-related protein. Expression of the gene-encoding phenylalanine ammonia-lyase (PAL) homolog can play a role in systemic plant resistance against the pathogens (Mishra et al. 2018).

\section{Conclusions}

The results indicate that application of the bioagents $T$. viride and $P$. chrysogenum as well as the extract of $C$. colocynthis could play a significant role in the protection of onions against Botrytis disease, mainly through the induction of the systemic resistance and enhancement of the antioxidant production in onions. Based on the in vitro and in vivo results, the application of such bio-products in the control of Botrytis disease on the field scale to reduce the usage of the harmful chemicals in agriculture and conserve the public health in the future is recommended.

\section{Abbreviations}

GLC: Gas-liquid chromatography; PAL: Phenylalanine ammonia-lyase; PO: Peroxidase activity; PPO: Polyphenoloxidase activity; TPC: Total phenol contents; TSW: Thousand seed weight

\section{Funding}

The authors extend their appreciation to the Deanship of Scientific Research at King Khalid University for funding this work through research groups program under grant number R.G.P. 1/43/39.
Authors' contributions

All authors contributed equally in the manuscript. All authors read and approved the final manuscript.

\section{Ethics approval and consent to participate}

This manuscript is in accordance with the guide for authors available on the journal's website. Also, this work has not been published previously and is approved by all authors and host authorities.

\section{Consent for publication}

All authors approve to publication

\section{Competing interests}

The authors declare that they have no competing interests.

\section{Publisher's Note}

Springer Nature remains neutral with regard to jurisdictional claims in published maps and institutional affiliations.

\section{Author details}

${ }^{1}$ Plant Pathology Department, Faculty of Agriculture, Assiut University, Assiut 71526, Egypt. ${ }^{2}$ Faculty of Science, Biology Department, King Khalid University, Abha, Saudi Arabia. ${ }^{3}$ Faculty of Science, Botany and Microbiology

Department, Assiut University, Assiut, Egypt.

Received: 3 June 2018 Accepted: 25 September 2018

Published online: 04 October 2018

\section{References}

Abdel-Hafez SI, Abo-Elyousr KAM, Abdel-Rahim IR (2015) Leaf surface and endophytic fungi associated with onion leaves and their antagonistic activity against Alternaria porri. Czech Mycol 67(1):1-22.

Abdel-Monaim MF, Abo-Elyousr KAM, Morsy K (2011) Effectiveness of plant extracts on suppression of damping-off and wilt diseases of lupine Lupinus termis Forsik. Crop Prot 30:185-191.

Abdel-Rahim I, Abo-Elyousr KAM (2018) Talaromyces pinophilus strain AUN-1 as a novel mycoparasite of Botrytis cinerea, the pathogen of onion scape and umbel blights. Microbiol Res 212-213 C:1-9.

Abo-Elyousr KAM, Abdel Hafez SI, Abdel Rahim I (2014) Isolation of Trichoderma and evaluation of their antagonistic potential against Alternaria porri. J Pytopathology 162:567-574.

Abo-Elyousr KAM, Asran MR (2009) Antibacterial activity of certain plant extracts against bacterial wilt of tomato. Arch Phytopatho Plant Protec 42:573-578. 
Abo-Elyousr KAM, Khan Z, Awad ME, Abdel-Moneim MF (2010) Efficacy of some plant extracts and Pseudomonas spp. against root-knot nematode, Meloidogyne incognita on tomato. Nematropica 40:289-300.

Ainsworth GC (1971) Ainsworth and Bisby's dictionary of the fungi, 6th. Commonwealth Mycological Institute, Kew, Surrey, England, p 663.

Arshad MS, Sohaib M, Nadeem M, Saeed F, Imran A, Javed A, Amjad Z, Batoo SM (2017) Status and trends of nutraceuticals from onion and onion byproducts: a critical review. Cogent Food Agric 3:1280254.

Avis T (2007) Antifungal compounds that target fungal membranes: applications in plant disease control. Can J Plant Pathol 29:323-329.

Ballard SA, Lodola A, Tarbit MH (1988) A comparative study of 1-substituted imidazole and 1, 2, 4-triazole antifungal compounds as inhibitors of testosterone hydroxylations catalysed by mouse hepatic musomal cytochromes P-450. Biochem. Pharmacol 37:4643-4651.

Batra G, Kuhn C (1975) Polyphenoloxidase and peroxidase activities associated with acquired resistance and its inhibition by 2-thiouracil in virus-infected soybean. Physiol Plant Pathol 5:239-248.

Baysal Ö, Gürsoy YZ, Örnek H, Duru A (2005) Induction of oxidants in tomato leaves treated with DL- $\beta$-amino butyric acid (BABA) and infected with Clavibacter michiganensis ssp. michiganensis. Eur J Plant Pathol 112(4):361369.

Benhamou N, Gagné S, Le Quéré D, Dehbi L (2000) Bacterial-mediated induced resistance in cucumber: beneficial effect of the endophytic bacterium Serratia plymuthica on the protection against infection by Pythium ultimum. Phytopathology 90(1):45-56.

Bestwick CS, Brown IR, Mansfield JW (1998) Localized changes in peroxidase activity accompany hydrogen peroxide generation during the development of a nonhost hypersensitive reaction in lettuce. Plant Physiol 118(3):1067-1078.

Bouziane Z, Dehimat L, Benabdelkader M (2011) The antagonism between Trichoderma viride and other pathogenic fungal strains in Zea mays. ABJNA 2(4):584-590.

Chance B, Maehly A (1955) Assay of catalases and peroxidases. Methods Enzymol 2:764-775.

Domsch KH, Gams W, Anderson T (1980) Compendium of soil fungi. Vol.1 \& 11. Acad. Press, London, p 672.

Dorant E, Van Din Brandt P, Goldbohm R (1994) A prospective cohort study on Allium vegetable consumption, garlic supplement use, and the risk of lung carcinoma in the Netherlands. Cancer Res 54:6148-6153.

Elad Y, Kapat A (1999) The role of Trichoderma harzianum protease in the biocontrol of Botrytis cinerea. Eur J Plant Pathol 105:177-189.

El-Aweel M, Ghobashi A (1999) Seed production in onion as influenced by dates of planting in the Sultanate of Oman. Assi J Agri Sci 30:16-21.

Ellis MB (1971) Dematiaceous hyphomycetes. Dematiaceous hyphomycetes. CMI, Commonwealth Mycological Institute, Kew, p 608.

Eltaweel M (2013) Assessment of antimicrobial activity of onion extract (Allium сера) on Staphylococcus aureus; in vitro study. Int Conf Chem, Agric Med Sci (CAMS):29-30. https://doi.org/10.15242/IICBE1213068.

Fandohan PD, Gbenou J, Gnonlonfin B, Hell K, Marasas WF, Wingfield MJ (2004) Effect of essential oils on the growth of Fusarium verticillioides and fumonisin contamination in corn. J Agric Food Chem 52:6824-6829.

Filonow A, Vishniac H, Anderson J, Janisiewicz W (1996) Biological control of Botrytis cinerea in apple by yeasts from various habitats and their putative mechanisms of antagonism. Biol Control 7:212-220.

Gomez KA, Gomez AA (1984) Statistical procedures for agricultural research, 2nd edn. John Willey, New York, p 680.

Hazarika DK, Das KK (1998) Biological management of root rot of french bean (Phaseolus vulgaris L.) caused by Rhizoctonia solani. P1ant Dis Res 13(2):101-105.

Hoevermann W, Rapp A, Ziegler A (1973) Method for separating phenolic acids by high pressure liquid chromatography. Chromatographia 6:317-319.

Hussein M, Hassan M, Allam A, Abo-Elyousr KAM (2007) Management of Stemphylium blight of onion by using biological agents and resistance inducers. Egy J Phytopathol 35:49-60.

Hussein M, Hassan M, Abo-Elyousr KAM (2014) Biological control of Botrytis allii by Trichoderma viride on onion (Allium cepa). World Appl Sci J 32(3):522-526.

Ishaq F, Khan A (2011) Isolation, identification and comparative study of fungal and bacterial strains found in organic and inorganic soils of different agricultural fields. Rec Res Sci Techno 3(11):30-36.

Khaledi N, Taheri P, Tarighi S (2015) Antifungal activity of various essential oils against Rhizoctonia solani and Macrophomina phaseolina as major bean pathogens. J Appl Microbiol 118(3):704-717.
Koul O, Walia S (2009) Comparing impacts of plant extracts and pure allelochemicals and implications for pest control. CAB Reviews 4:1-30.

Lattanzio V, Di Venere D, Linsalata V, Lima G, Ippolito A, Salerno M (1996) Antifungal activity of 2,5-dimethoxybenzoic acid on postharvest pathogens of strawberry fruits. Postharvest Biol Technol 9:325-334.

Lee J, Mitchell AE (2011) Quercetin and isorhamnetin glycosides in onion (Allium cepa L.): varietal comparison, physical distribution, coproduct evaluation, and long-term storage stability. J Agric Food Chem 59:857-863.

Lisker N, Cohen L, Chalutz E, Fuchs Y (1983) Fungal infections suppress ethyleneinduced phenylalanine ammonia-lyase activity in grapefruits. Physiol Plant Pathol 22:331-338.

Liu S, Ruan W, Li J, Xu H, Wang J, Gao Y, Wang J (2008) Biological control of phytopathogenic fungi by fatty acids. Mycopathologia 166:93-102.

Mayer AM (2006) Polyphenoloxidases in plants and fungi: going places? A review. Phytochemistry 67:2318-2331.

Mishra A, Singh SP, Mahfooz S, Singh SP, Bhattacharya A, Mishra N, Nautiyal CS (2018) Endophyte-mediated modulation of defense-related genes and systemic resistance in Withania somnifera (L.) Dunal under Alternaria alternata stress. Appl Environ Microbiol 84:e02845-e02817. https://doi.org/10.1128/ AEM.02845-17.

Nagaraja T, Sarang S, Jambhale D (2008) Evaluation of anti-mycotic activity of Acacia catechu Willd. (Mimosaceae). J Biopestici 1:197-198.

Nascimento KJT, Araujo L, Resende RS, Schurt DA, Silvav WLD, Rodrigues FDA (2016) Silicon, acibenzolar-Smethyl and potassium phosphite in the control of brown spot in rice. Bragantia 75:212-221.

Pitt JI (1979) The genus Penicillium and it's teleomorphic states Eupenicillium and Talaromyces. Academic press. INC. LTD, London.

Rahman MM, Gray Al (2005) A benzoisofuranone derivative and carbazole alkaloids from Murraya koenigii and their antimicrobial activity. Phytochemistry 66:1601-1606.

Rais A, Jabeen Z, Shair F, Hafeez FY, Hassan MN (2017) Bacillus spp., a bio-control agent enhances the activity of antioxidant defense enzymes in rice against Pyricularia oryzae. PLoS One 12(11):e0187412.

Raj TS, Anandeeswari D, Suji H, Joice AA (2016) Role of defence enzymes activity in rice as induced by idm formulations against sheath blight caused by Rhizoctonia solani. IJAPSA 2:106-116.

Reddy M, Ilao RI, Faylon PS (2014) Recent advances in biofertilizers and biofungicides (PGPR) for sustainable agriculture. Cambridge Scholars Publishing, Newcastle upon Tyne, NE6 2XX, p 510.

Rifai MA (1969) A revision of the genus Trichoderma. Mycol Pap 116:1-56.

Sales MD, Costa HB, Fernandes PM, Ventura JA, Meira DD (2016) Antifungal activity of plant extracts with potential to control plant pathogens in pineapple. Asian Pac J Trop Dis 6:26-31.

Seleim MA, Abo-Elyousr KAM, Mohamed AAA, Al-Marzoky HA (2014) Peroxidase and polyphenoloxidase activities as biochemical markers for biocontrol efficacy in the control of tomato bacterial wilt. Plant Physiol Pathol 2:2-8.

Senthilraja GT, Anand J, Kennedy T, Raguchander T, Samiyappan R (2013) Plant growth promoting rhizobacteria (PGPR) and entomopathogenic fungus bioformulation enhance the expression of defense enzymes and pathogenesis-related proteins in groundnut plants against leafminer insect and collar rot pathogen. Physiol Mol Plant Pathol 82:10-19.

Shoaib A, Munir M, Javaid A, Awan ZA, Rafiq M (2018) Anti-mycotic potential of Trichoderma spp. and leaf biomass of Azadirachta indica against the charcoal rot pathogen, Macrophomina phaseolina (Tassi) Goid in cowpea. Egyp J Biolo Pest Control 28(1):26.

Singh J, Tripathi N (1999) Inhibition of storage fungi of blackgram (Vigna mungo L.) by some essential oils. Flavour Fragr J 14:1-4.

Soria S, Alonso R, Bettucci L (2012) Endophytic bacteria from Pinus taeda L. as biocontrol agents of Fusarium circinatum Nirenberg \&O'donnell. Chil J Agr Res 72:281-284.

Sun T, Powers JR, Tang J (2007) Evaluation of the antioxidant activity of asparagus, broccoli and their juices. Food Chem 105:101-106.

Thakur A (2017) Evaluation of biological control strategies against a range of plant pathogens. Master Thesis Agriculture Univ, Athens, p 92.

Ud-Deen MM (2008) Effect of mother bulb size and planting time on growth, bulb and seed yield of onion. BJAR 33:531-537.

Velioglu Y, Mazza G, Gao L, Oomah B (1998) Antioxidant activity and total phenolics in selected fruits, vegetables, and grain products. J Agric Food Chem 46:4113-4117.

Wang C, Zhang J, Chen H, Fan Y, Shi Z (2010) Antifungal activity of eugenol against Botrytis cinerea. Trop Plant Pathol 35:137-143. 
Yasmin S, Zaka A, Imran A, Zahid MA, Yousaf S, Rasul G, Arif M, Mirza MS (2016) Plant growth promotion and suppression of bacterial leaf blight in rice by inoculated bacteria. PLoS One 11:e01606.

Yu H, Du X (2018) Differential regulation of calmodulin, phenylalanine ammonialyase, and salicylic acid in response to Botrytis cinerea infection in tomato with different Ca2+ concentrations. J Plant Nut 41(9):1104-1118.

Ziedan E (1998) Integrated control of wilt and root-rot diseases of sesame in ARE. Ph. D. Thesis, Faculty of Agric. Ain Shams University, Cairo, p 146.

Zimand G, Elad Y, Chet I (1996) Effect of Trichoderma harzianum on Botrytis cinerea pathogenicity. Phytopathology 86:1255-1260.

\section{Submit your manuscript to a SpringerOpen ${ }^{\circ}$ journal and benefit from:}

- Convenient online submission

- Rigorous peer review

- Open access: articles freely available online

High visibility within the field

- Retaining the copyright to your article

Submit your next manuscript at $\boldsymbol{\nabla}$ springeropen.com 